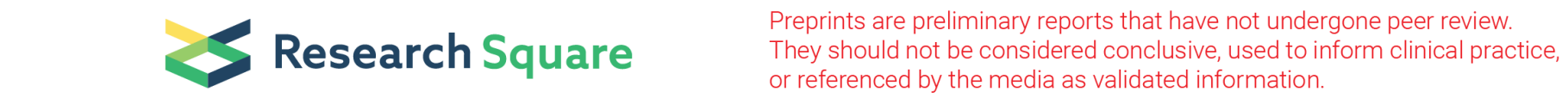

\title{
Clinical and Prognostic Role of Vasohibin-1 Expression in Solid Tumors
}

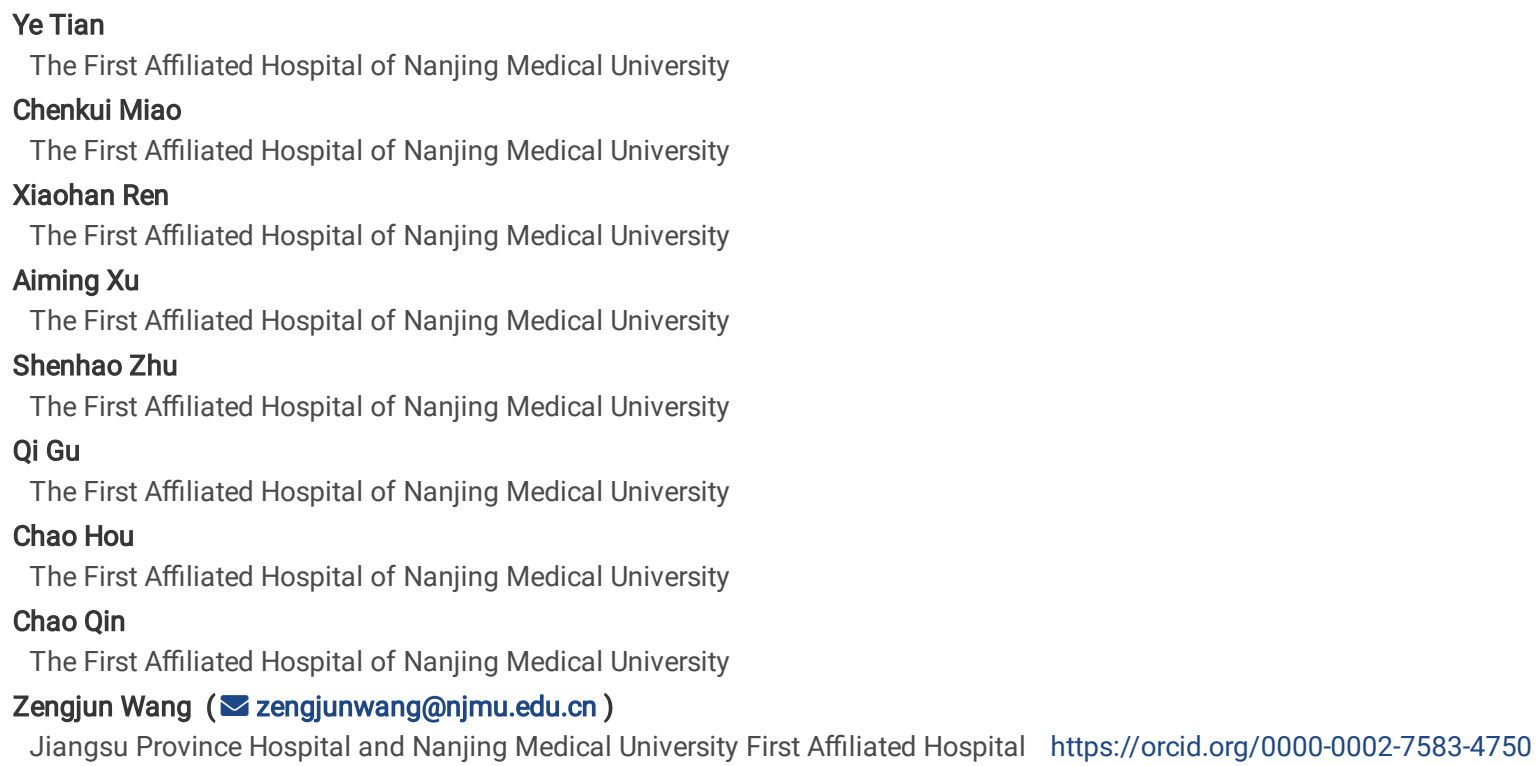




\section{Abstract}

Background

The role of Vasohibin-1 (VASH1) expression in solid tumors remains controversial. We thus performed this meta-analysis to elucidate the associations between VASH1 expression and the prognosis of solid tumors.

Methods

We searched relevant literature in PubMed, Web of Science and EMBASE. The hazard ratio (HR) or odds ratio (OR) and 95\% confidence intervals (Cls) were measured by fixed-effects or random-effects models. Publication bias was assessed using funnel plots and Egger's regression test.

Results

The results showed that VASH1 expression exhibited a significantly decreased overall survival (OS) time $(\mathrm{HR}=1.85 ; 95 \% \mathrm{Cl}=1.27-2.69)$ and disease-free survival (DFS) $(\mathrm{HR}=1.80 ; 95 \% \mathrm{Cl}=1.41-2.29)$ time. Meanwhile, $\mathrm{VASH} 1$ expression was found significantly associated with $\mathrm{TNM}$ stage $(\mathrm{OR}=1.96 ; 95 \% \mathrm{Cl}=$ 1.57-2.46), tumor stage $(\mathrm{OR}=2.35 ; 95 \% \mathrm{Cl}=1.88-2.93)$, lymph node metastasis $(\mathrm{OR}=2.02 ; 95 \% \mathrm{Cl}=1.37-2.98)$, venous invasion $(\mathrm{OR}=1.63 ; 95 \% \mathrm{Cl}=1.00$ 2.65), tumor grade $(\mathrm{OR}=1.74 ; 95 \% \mathrm{Cl}=1.13-2.67)$ and microvessel density (MVD) $(\mathrm{OR}=4.30 ; 95 \% \mathrm{Cl}=2.31-8.03)$. However, no significant association was found between the VASH1 expression and distant metastasis $(\mathrm{OR}=1.81 ; 95 \% \mathrm{Cl}=0.74-1.41)$.

Conclusion

This study demonstrated that VASH1 expression was relevant to more aggressive clinicopathological parameters and might predict inferior DFS and OS in solid tumor patients.

\section{Background}

Cancer is a deadly disease that has plagued mankind for centuries and is still growing at a terrifying rate, with an estimated more than $14,400,000$ new cases all over the world, partly owing to the change of lifestyle and increased life expectancy [1]. The occurrence of cancer is due to many factors, such as dietary factors, carcinogen exposure, radiation, individual difference, et al [2]. Even though the exact mechanism is not entirely clear, the subtle correlation between some biological behaviors and cancer is being investigated, for example, angiogenesis [3]. Tumor angiogenesis, normally regulated by a relative balance between stimulatory and inhibitory factors, has been regarded as a key catalyst for tumor progression, metastasis and poor prognosis in most cases [4, 5]

VASH1, a member of vasohibin protein family, has been identified as an endogenous inhibitor of angiogenesis and expressed in endothelial cells (ECs) [6]. Consisting of eight exons and seven introns, its genes localize at chromosome 14q24.3, which could be induced by vascular endothelial growth factor (VEGF) and fibroblast growth factor 2 (FGF-2) [4]. Considering that angiogenic disorder is one of the hallmarks of cancer, as an important vascular regulator, VASH1 may accelerate or inhibit the genesis and progression of cancer in some ways [7]. In reality, to explore the role of VASH1 on cancers, scholars have carried out many experiments (or researches) and achieved preliminary results. For example, Wang et al. retrospected 117 patients with primary hepatocellular carcinoma (HCC), which manifested that high expression of VASH1 could result in more adverse clinical and prognostic outcomes [8]. Furthermore, from a study conducted by Miyazaki et al, a negative correlation was found between VASH1 and tumor grade, microvessel density (MVD) and five-years survival rate [9]. But reversely, another experiment conducted by Li et al., which based on rodent model, stated that VASH1 might inhibit the proliferation and metastasis of HCC and therefore prolong the life of experimental mice [10]. By retrospectively analysing the data from 118 consecutive renal cell carcinomaclear (RCC) patients, Kanomata et al. have yielded a similar conclusion - a higher VASH1 expression was observed with significantly shorter OS [11]. The discrepancies between these studies highlight the importance of evaluating the clinical and prognostic significance of VASH1 in human malignant neoplasms.

We, therefore, performed this study to provide a more rigorous assessment of existing clinical and prognostic data by systematically reviewing the studies reporting VASH1 and corresponding outcomes. We reviewed and conducted a meta-analysis of these studies which reported the relationship between VSAH1 expression and the following outcomes: TNM stage, tumor stage (T stage), lymph node metastasis ( $\mathrm{N}$ stage), distant metastasis (M stage), venous invasion, tumor grade, MVD, OS, and DFS in solid tumors.

\section{Methods}

\section{Literature search and inclusion criteria}

This meta-analysis part followed the PRISMA guidelines [12]. The literature retrieval was performed by two independent members of the author team (Ye Tian and Chenkui Miao) in electronic databases including PubMed, Web of Science and EMBASE databases from inception until January 2020. The search strategy in PubMed included the following domains: "Vasohibin-1", "Vasohibin 1", "VASH1", "cancer", "carcinoma", "neoplasm", "tumor ", and "malignancy". These terms were combined with "AND" or "OR". Web of Science and EMBASE searches were completed with the authors' terminology. Also, the reference lists of included studies and related comments were manually filtered for new studies that may be relevant.

Studies were included if they: (1) were studies on malignant tumor; (2) evaluated the relationship between VASH1 expression and clinical outcomes; (3) reported the clinicopathological parameters in study patients; (4) included the control group. To supplement our literature searching, the reference lists of relevant articles were reviewed for eligibility.

\section{Data extraction}


All records were independently evaluated by three investigators (Ye Tian, Chenkui Miao, Xiaohan Ren) through title, abstract and full-text screening. Any discrepancies about record eligibility were resolved by a discussion between two members as well as a fourth author (Qi Gu). All studies meeting inclusion criteria were retained in the analysis.

For each included record, two investigators independently extracted relevant data to rule out any discrepancies. Disagreements were resolved by a discussion between two investigators. The following data were recorded from all eligible studies: (1) the first author's name and year of publication, (2) the study nationality, (3) cancer types, (4) sample and pathology type, (5) the cut-off value and assay method, (6) following-up months, (7) the case number of VASH1 relatively-high expression and prognostic outcomes. Those indirectly reported HRs and $95 \%$ Cls were extracted from graphical survival plots using Engauge Digitizer version 4.1 (markmitch, Boston, USA) [13].

\section{Quality Assessment}

We used the Newcastle-Ottawa scale (NOS) score to independently evaluated the study quality, which allows for the evaluation of methods of patient selection, comparability of study groups, and reporting of essential outcomes [14]. With the score ranging from 0 to 9 , studies with scores $\geq 6$ were graded as high quality. Details are available in Table 1.

\section{Statistical analysis}

Stata version 16.0 (Stata Corporation, College Station, TX, USA) was used to calculate all statistical analyses. All reported P-values were two-sided, with $\mathrm{p}<0.05$ defined as statistically significant. Testing for the heterogeneity of pooled effects (HR; OR), Cochrane Q-test [15] and the inconsistency index value (I2) [16] were performed in the meta-analysis. The fixed-effects model or random-effects model was selected following the heterogeneity of included studies. The funnel plot and Egger's test were used to judge the publication bias.

\section{Acquisition of data from TCGA and GTEx database}

The data of gene expression profile and survival information were obtained from the TCGA database (https://portal.gdc.cancer.gov/), which characterizes 33 cancer types including ten rare cancers. VASH1 mRNA expression levels across normal tissues were retrieved from Genotype-Tissue Expression (GTEx) Portal.

\section{Results}

\section{Characteristics of included studies}

The flowchart shows the literature retrieval and selection process (Figure 1). Using the search strategy in PubMed, Web of Science, EMBASE and the Cochrane Register of Controlled Trials databases, we initially collected a total of 132 studies, but 63 of them were excluded after screening the titles and abstracts. By further reviewing assessing the remaining studies, 30 studies were excluded for review articles, letters, research with non-human or not relevant to the current analysis. Eventually, 18 studies were identified as meeting our inclusion criteria [17-34], whose detailed information was shown in Table 2. The VASH1 relatively-low expression group (1225 individuals; 52.8\%) was regarded as the control group. The main assay method of all studies was immunohistochemistry (IHC).

\section{Clinicopathological parameters and VASH1 expression}

The pooled OR from 18 studies, including 1092 high VASH1 and 1225 low VASH1 individuals, shown in Figure 2-4 and Table 3. With the study of Liu et al. removed for sensitivity analysis, 10 studies estimated the association between VASH1 expression and TNM stage, indicating that a higher VASH1 expression in malignancy tissue may lead to worse TNM stage $(3 / 4)(\mathrm{OR}=2.35 ; 95 \% \mathrm{Cl}=1.88-2.93 ; \mathrm{I} 2=31.4 \%)$. Conceivably, as with the TNM stage, a significant adverse effect was found in the analysis of tumor stage $(\mathrm{OR}=1.96 ; 95 \% \mathrm{Cl}=1.57-2.46 ; \mathrm{I} 2=37.9 \%)$ and lymph node metastasis $(\mathrm{OR}=2.02 ; 95 \% \mathrm{Cl}=1.37-$ $2.98 ; \mathrm{I} 2=52.9 \%)$. However, no sufficient correlation was observed in distant metastasis $(\mathrm{OR}=1.81 ; 95 \% \mathrm{Cl}=0.74-4.41 ; 12=66.0 \%)$.

Moreover, the result reveled that high VASH1 expression exhibited a significant increased venous invasion $(\mathrm{OR}=1.63 ; 95 \% \mathrm{Cl}=1.00-2.65 ; \mathrm{I} 2=61.0 \%)$ and $\operatorname{MVD}(\mathrm{OR}=4.30 ; 95 \% \mathrm{Cl}=2.31-8.03 ; \mathrm{I} 2=75.8 \%)$. And interestingly, VASH1 expression may be related with poorly-differentiated tumor cells $(\mathrm{OR}=1.74 ; 95 \% \mathrm{Cl}$ $=1.13-2.67 ; 12=69.1 \%)$.

\section{Prognostic value of VASH1 expression for DFS and OS}

The correlation of VASH1 expression and survival outcomes is shown in Figure 4 and Table 3. A total of 14 studies comprising 1744 patients reported the effect of VASH-1 on DFS or OS in multiple tumors. For DFS, since no significant heterogeneity was observed among these studies ( $p=0.302,12=17.2 \%$, a fixed-effect model was utilized. The pooled $\mathrm{HR}$ with $95 \% \mathrm{Cl}$ suggested that high VASH-1 expression in tumor tissues was significantly associated with poor DFS (pooled HR $=1.80,95 \% \mathrm{Cl}: 1.41-2.29)$. Moreover, a higher VASH1 expression was observed with significantly shorter OS time (pooled HR $=1.87,95 \% \mathrm{Cl}$ : $1.27-2.69 ; 12=80.0 \%)$, same as the conclusion of DFS.

\section{Test of heterogeneity}

For the comparison of the lymph node metastasis, distant metastasis, venous invasion, AJCC stage, tumor grade, MVD and OS, moderate heterogeneity was observed. However, no heterogeneity was observed in TNM stage, tumor, and DFS.

\section{Sensitivity analysis}


Sensitivity analysis aimed at assessing whether the exclusion of any individual study influenced the overall results. Figure S1 revealed that the results were reliable, indicating that no individual study affected the pooled HR significantly.

\section{Publication bias}

The funnel plot (Figure 5) and Egger's test were used to assess publication bias. The funnel plot indicates that no significant publication bias for TNM stage, tumor, lymph node metastasis, distant metastasis, which were confirmed by Egger's test respectively $(P=0.219, P=0.113, P=0.784, P=0.535)$. Similarly, no publication bias was found in venous invasion (Egger's test : $P=0.915)$, tumor grade (Egger's test : $P=0.120), 0 S(E g g e r ' s$ test : $P=0.693)$ and DFS (Egger's test : $P=0.353$ ). However, we found publication bias in the analysis of MVD (Egger's test: $P=0.013$ ).

\section{The expression of VASH1 has a significant difference between tumor tissue and normal tissue of multiple cancers}

Figure 6 showed the VASH1 mRNA expression level after combining the gene expression data of TCGA and GTEx databases. The results indicated that VASH1 is overexpressed in lymphoid neoplasm diffuse large B-cell lymphoma (TCGA-DLBC), glioblastoma (TCGA-GBM), head and neck squamous cell carcinoma (TCGA-HNSC), kidney renal clear cell carcinoma (TCGA-KIRC), kidney renal papillary cell carcinoma (TCGA-KIRP), acute myeloid leukemia (TCGA-LAML), brain lower grade glioma (TCGA-LGG), liver hepatocellular carcinoma (TCGA-LIHC), pancreatic adenocarcinoma (TCGA-PAAD), sarcoma (TCGA-SARC), skin cutaneous melanoma (TCGA-SKCM), stomach adenocarcinoma (TCGA-STAD) and thymoma (TCGA-THYM). Conversely, it is downregulated in adrenocortical carcinoma (TCGA-ACC), bladder urothelial carcinoma (TCGA-BLCA), cervical squamous cell carcinoma and endocervical adenocarcinoma (TCGA-CESC), colon adenocarcinoma (TCGA-COAD), lung adenocarcinoma (TCGA-LUAD), lung squamous cell carcinoma (TCGA-LUSC), ovarian serous cystadenocarcinoma (TCGA-OV), prostate adenocarcinoma (TCGA-PRAD), rectum adenocarcinoma (TCGA-READ), testicular germ cell tumors (TCGA-TGCT), uterine corpus endometrial carcinoma (TCGA-UCEC) and uterine carcinosarcoma (TCGA-UCS).

\section{Discussion}

As an endogenous inhibitor of angiogenesis, VASH1 may play a pivotal role in maintaining vascular homeostasis, preventing pathological angiogenesis [35]. VASH1 may possess the duality functions - an experiment based on the mice model stated that the decrease of VASH1 resulted in a long lifespan, which contrary to the prime expectation of the experimenters [36]. Meanwhile, the feasible suppression and facilitation of VASH1 on tumors have of late years investigated by scholars and the results remain controversial [37, 38].

Meta-analysis can provide more reliable results compared with a single study and serves as a powerful tool to explain controversial conclusions. For this reason, we performed a meta-analysis to clarify whether VASH1 expression has a significant impact on the clinical and prognostic outcomes of cancer. To our knowledge, this is the first complete meta-analysis concerning the role of VASH1 in solid tumors. In our analysis, we found that VASH expression was relevant to more aggressive clinicopathological parameters and might predict inferior DFS and OS in cancer patients.

The result of our analysis showed that high expression of VASH1 might be associated with more inferior TNM stage, tumor stage, lymph node metastasis, distant metastasis and tumor grade, same as the conclusion with many studies, for example, Cao et al. and Zhang et al. [39, 40]. Despite the concrete mechanism not being clearly understood, an accountable explanation is that - in the process of tumor angiogenesis, the out-off-balance between VASH1 and VEGF may lead to the formation of numerous new blood vessels with fragmentary structure or lack of basement membrane, although the inhibition role of VASH1 in tumor vascularization. And the noteworthy increase of vascular permeability caused by this imbalance could further accelerate the proliferation and metastasis of cancer cells [41]. Put another way, VASH1 suppresses tumor angiogenesis but not the tumor cells.

MVD, as an independent predictor of poor prognosis, is generally regarded connected with clinical outcome, for instance, tumor grade, pathologic stage et al. $[42,43]$. Additionally, from the present analysis, an advanced relevance between venous invasion, MVD, and VASH1 expression was found, which was opposite to our expectations. Interestingly, considering that the indispensable effect of VASH1 on maintaining vascular health and inhibiting angiogenesis, this unexpected result is worth a thorough discussion. Firstly, as we know, VASH1 is induced by angiogenic factors, to illustrate, VEGF and FGF-2 [4]. There is a positive relevance between the intensity of VASH1 and VEGFA in tumor cells [31,44]. Nevertheless, with VASH1 degraded and inactivated after its secretion in the tumor microenvironment, the IHC staining of VASH1 in vascular ECs may not demonstrate its anti-angiogenic activity, but only reflect the response of ECs to angiogenic stimulation [45]. Secondly, as a feedback regulator of angiogenesis, VASH1 is up-regulated with VEGFA expression. Yet this endogenous upregulation is not enough to inhibit neovascularization. Researchers found that in tumor tissue, not only MVD expression increased but also the more ripe microvasculature where the VASH1 mainly expressed [46]. These mature vasculature may supply more nutrition for tumors, and therefore facilitate tumor growth and distant metastasis. Consequently, the increase of VASH1 expression may be associated with the enhancement of tumor invasiveness [25, 27]. Thirdly, VASH1 might be an activator or inhibitor of angiogenic factor mRNA translation, and this dual functional role may be the reason for VASH1 to inhibit angiogenesis and to profit ECs survival $[47,48]$.

Finally, our results showed that the higher expression of VASH1 associated with shorter DFS and OS time, which was in line with conclusions from most studies [33,34]. From our perspective, the high expression of VASH1 is related to worse clinicopathological features and thus shorten survival time. However, the results of the OS time showed high heterogeneity, which might be caused by different types of solid tumors.

Furthermore, despite the overall robust statistical evidence generated through this analysis, some limitations have been identified. Firstly, owing to the limited quantity of the studies included, further subgroup analysis is unavailable, for example, cancer types. Secondly, IHC based VASH1 detection has limitations for its subjectivity in determining a clear definition of "positive (or high)" tumor VASH1 staining. Meanwhile, different studies had different definitions of positive expression of VASH1 (final scores, VASH1 density, IHC expression level, et al. ), and thus more uniform standards need to be established. Thirdly, only the 
Asian population was applicable in this meta-analysis, which might minimize the analyzing value to some level. Moreover, the difference in samples from different institutions might reduce the credibility of our conclusion, which serves as an unavoidable factor in the study.

\section{Conclusion}

In conclusion, our meta-analysis suggested that high expression of VASH1 could act as a common maker to predict a high risk of clinical outcomes and poor OS or DFS in patients with a solid tumor. However, based on the limitations of this meta-analysis, large size, and better design studies are needed to validate the clinical role of VASH1.

\section{Abbreviations}

VASH1: Vasohibin-1

HR: hazard ratio

OR: odds ratio

Cls: confidence intervals

DFS: disease-free survival

ECs: endothelial cells

VEGF: vascular endothelial growth factor

FGD-2: fibroblast growth factor 2

HCC: hepatocellular carcinoma

MVD: microvessel density

RCC: renal cell carcinomaclear

T stage: tumor stage

N stage: lymph node metastasis

M stage: distant metastasis

NOS: Newcastle-Ottawa scale

IHC: immunohistochemistry

\section{Declarations}

\section{Ethics approval and consent to participate}

Not applicable.

\section{Consent for publication}

Not applicable.

\section{Availability of data and materials}

The datasets supporting the conclusions of this article are included within the article and its additional files.

\section{Competing interests}

The author declares that they have no competing interests.

\section{Funding}

The study was supported by the National Natural Science Foundation of China (Grants nos. 81270685 and 81771640); National key research and development program for cohort study of suspected prostate cancer (2017YFC0908002-1) 『Nanjing Medical University Science and Technology Development Fund (NMUC2018003A); Postgraduate Research \& Practice Innovation Program of Jiangsu Province (KYCX19_1159/JX10213635); International Exchange and Cooperation Program for Postgraduates of Nanjing Medical University. 
YT and MC collected the data and performed the meta-analysis. YT wrote the manuscript. All the authors participated in the data analysis and approved the final version of the manuscript.

\section{Acknowledgements}

Not applicable.

\section{References}

[1] Torre LA, Siegel RL, Ward EM, Jemal A. Global Cancer Incidence and Mortality Rates and Trends-An Update. Cancer Epidemiol Biomarkers Prev. 2016; 25(1): 16-27.

[2] Sharma KL, Rai R, Srivastava A, Sharma A, Misra S, Kumar A, et al. A multigenic approach to evaluate genetic variants of PLCE1, LXRs, MMPs, TIMP, and CYP genes in gallbladder cancer predisposition. Tumour Biol. 2014; 35: 8597-8606.

[3] Nowak-Sliwinska P, Alitalo K, Allen E, Anisimov A, Aplin AC, Auerbach R, et al. Consensus guidelines for the use and interpretation of angiogenesis assays. Angiogenesis. 2018; 21(3): 425-532.

[4] Gong FL, Wang L, Yu LG, Dang YF, Jiang XN1, Zhao L, et al. DHPAC, a novel microtubule depolymerizing agent, suppresses angiogenesis and vasculogenic mimicry formation of human non-small cell lung cancer. J Cell Biochem. 2020 Feb 14.

[5] Nienhüser H, Schmidt T. Angiogenesis and Anti-Angiogenic Therapy in Gastric Cancer. Int J Mol Sci. 2017; 19(1). pii: E43.

[6] Du H, Zhao J, Hai L, Wu J, Yi H, Shi Y. The roles of vasohibin and its family members: Beyond angiogenesis modulators. Cancer Biol Ther. 2017; 18(11): 827-832.

[7] Hosaka T, Kimura H, Heishi T, Suzuki Y, Miyashita H, Ohta H, et al. Vasohibin-1 expressed in endothelium of tumor vessels regulates angiogenesis. Am J Pathol. 2009; 175: 430-439.

[8] Wang Q, Tian X, Zhang C, Wang Q. Upregulation of vasohibin-1 expression with angiogenesis and poor prognosis of hepatocellular carcinoma after curative surgery. Med Oncol. 2012; 29(4): 2727-36.

[9] Miyazaki Y, Kosaka T, Mikami S, Kikuchi E, Tanaka N, Maeda T, et al. The prognostic significance of vasohibin-1 expression in patients with upper urinary tract urothelial carcinoma. Clin Cancer Res. 2012; 18(15): 4145-4153.

[10] Li D, Zhou K, Wang S, Shi Z, Yang Z. Recombinant adenovirus encoding vasohibin prevents tumor angiogenesis and inhibits tumor growth. Cancer Sci. 2010; 101(2): 448-452.

[11] Kanomata N, Sato Y, Miyaji Y, Nagai A, Moriya T. Vasohibin-1 is a new predictor of disease-free survival in operated patients with renal cell carcinoma. J Clin Pathol. 2013; 66(7): 613-9.

[12] Moher D, Liberati A, Tetzlaff J, Altman DG, The PRISMA Group. Preferred Reporting Items for Systematic Reviews and Meta-Analyses: The PRISMA Statement. Int J Surg. 2010; 8(5): 336-41.

[13] Tierney JF, Stewart LA, Ghersi D, Burdett S, Sydes MR. Practical methods for incorporating summary time-to-event data into meta-analysis. Trials. 2007; 8: 16.

[14] Wells G, Shea B, O'Connell D, Peterson J, Welch V, Losos M, et al. The Newcastle-Ottawa Scale (NOS) for Assessing the Quality if Nonrandomized Studies in Meta-Analyses, http://www. ohri.ca/programs/clinical_epidemiology/oxford.asp, Accessed 15 December 2019.

[15] Lau J, loannidis JP, Schmid CH. Quantitative synthesis in systematic reviews. Ann Intern Med. 1997; 127: 820-826.

[16] Higgins JP, Thompson SG, Deeks JJ, Altman DG. Measuring inconsistency in meta-analyses. BMJ. 2003; 327: 557-560.

[17] Yu L, Mao X, Jiao Y, Song W, Wang D. Expression of vasohibin-1, MACC1 and KA11 proteins in serous ovarian cancer and their clinical significance. Zhong Nan Da Xue Xue Bao Yi Xue Ban. 2019; 44(12): 1344-1352.

[18] Yu L, Mao X, Wu S, Zhou L, Song W, Gong X, et al. The correlation of the expressions of WWOX, LGR5 and vasohibin-1 in epithelial ovarian cancer and their clinical significance. Int J Clin Exp Pathol. 2019; 12(1): 327-336.

[19] Ninomiya Y, Ozawa S, Oguma J, Kazuno A, Nitta M, Kajiwara H, et al. Expression of vasohibin-1 and -2 predicts poor prognosis among patients with squamous cell carcinoma of the esophagus. Oncol Lett. 2018; 16(4): 5265-5274.

[20] Wu SW, Wang YC, Ci HF, Tao YS. Expression of vasohibin-1 and MACC1 in lung squamous cell carcinoma and their clinicopathological significance. Nan Fang Yi Ke Da Xue Xue Bao. 2017; 37(7): 952-956.

[21] Ma D, Li J, Wang J, Sun Z, Wang K. Clinical implications of vasohibin-1 in esophageal carcinoma cells: Inhibition of cell growth and migration. Mol Med Rep. 2017; 16(2): 1479-1485. 
[22] Sano R, Kanomata N, Suzuki S, Shimoya K, Sato Y, Moriya T, et al. Vasohibin-1 Is a Poor Prognostic Factor of Ovarian Carcinoma. Tohoku J Exp Med. $2017 ; 243(2):$ 107-114.

[23] Torii C, Hida Y, Shindoh M, Akiyama K, Ohga N, Maishi N, et al. Vasohibin-1 as a Novel Prognostic Factor for Head and Neck Squamous Cell Carcinoma. Anticancer Res. 2017; 37(3): 1219-1225.

[24] Mikami S, Oya M, Kosaka T, Mizuno R, Miyazaki Y, Sato Y, et al. Increased vasohibin-1 expression is associated with metastasis and poor prognosis of renal cell carcinoma patients. Lab Invest. 2017; 97(7): 854-862.

[25] Shen Z, Yan Y, Ye C, Wang B, Jiang K, Ye Y, et al. The effect of Vasohibin-1 expression and tumor-associated macrophages on the angiogenesis in vitro and in vivo. Tumour Biol. 2016; 37(6): 7267-76.

[26] Liu S, Han B, Zhang Q, Dou J, Wang F, Lin W, et al. Vasohibin-1 suppresses colon cancer. Oncotarget. 2015; 6(10): 7880-7898.

[27] Murakami K, Kasajima A, Kawagishi N, Sekiguchi S, Fujishima F, Watanabe M, et al. The prognostic significance of vasohibin 1-associated angiogenesis in patients with hepatocellular carcinoma. Hum Pathol. 2014; 45(3): 589-97.

[28] Yan Y, Shen Z, Ye Y, Jiang K, Zhang H, Shen C, et al. A novel molecular marker of prognosis in colorectal cancer: Vasohibin-1. Med Oncol. 2014; 31(2): 816.

[29] Zhang T, Yu TT, Zhang DM, Hou XM, Liu XJ, Zhao D, et al. Vasohibin-1 expression detected by immunohistochemistry correlates with prognosis in nonsmall cell lung cancer. Med Oncol. 2014; 31(5): 963.

[30] Kitajima T, Toiyama Y, Tanaka K, Saigusa S, Kobayashi M, Inoue Y, et al. Vasohibin-1 increases the malignant potential of colorectal cancer and is a biomarker of poor prognosis. Anticancer Res. 2014; 34(10): 5321-5329.

[31] Kosaka T, Miyazaki Y, Miyajima A, Mikami S, Hayashi Y, Tanaka N, et al. The prognostic significance of vasohibin-1 expression in patients with prostate cancer. Br J Cancer. 2013; 108(10): 2123-2129.

[32] Kanomata N, Sato Y, Miyaji Y, Nagai A, Moriya T. Vasohibin-1 is a new predictor of disease-free survival in operated patients with renal cell carcinoma. J Clin Pathol. 2013; 66(7): 613-9.

[33] Miyazaki Y, Kosaka T, Mikami S, Kikuchi E, Tanaka N, Maeda T, et al. The prognostic significance of vasohibin-1 expression in patients with upper urinary tract urothelial carcinoma. Clin Cancer Res. 2012; 18(15): 4145-4153.

[34] Wang Q, Tian X, Zhang C, Wang Q. Upregulation of vasohibin-1 expression with angiogenesis and poor prognosis of hepatocellular carcinoma after curative surgery. Med Oncol. 2012; 29(4): 2727-2736.

[35] Sato Y. Double-Face of Vasohibin-1 for the Maintenance of Vascular Homeostasis and Healthy Longevity. J Atheroscler Thromb. 2018; 25(6): 461-466.

[36] Takeda E, Suzuki Y, Yamada T, Takagiri H, Sato Y. Knockout of vasohibin-1 gene in mice results in healthy longevity with reduced expression of insulin receptor, insulin receptor substrate 1, and insulin receptor substrate 2 in their white adipose tissue. J Aging Res. 2017; $2017: 9851380$.

[37] Zhou CF, Ma J, Huang L, Yi HY, Zhang YM, Wu XG, et al. Cervical squamous cell carcinoma-secreted exosomal miR-221-3p promotes lymphangiogenesis and lymphatic metastasis by targeting VASH1. Oncogene. 2019; 38(8): 1256-1268.

[38] Watanabe T, Hosaka T, Ohmori-Matsuda K, Suzuki Y, Suzuki H, Yabuki H, et al. High preoperative plasma vasohibin-1 concentration predicts better prognosis in patients with non-small cell lung carcinoma. Health Sci Rep. 2018; 1(6): e40.

[39] Cao L, Sun PL, He Y, Yao M, Gao H. Desmoplastic Reaction and Tumor Budding in Cervical Squamous Cell Carcinoma are Prognostic Factors for Distant Metastasis: A Retrospective Study. Cancer Manag Res. 2020; 12: 137-144.

[40] Zhang B, Wu Z, Xie W, Tian D, Chen F, Qin C, et al. The expression of vasohibin-1 and its prognostic significance in bladder cancer. Exp Ther Med. 2017; 14(4): 3477-3484.

[41] Li D, Zhou K, Wang S, Shi Z, Yang Z. Recombinant adenovirus encoding vasohibin prevents tumor angiogenesis and inhibits tumor growth. Cancer Sci. 2010; 101: 448-452.

[42] den Uil SH, van den Broek E, Coupé VMH, Vellinga TT, Delis-van Diemen PM, Bril H, et al. Prognostic value of microvessel density in stage II and III colon cancer patients: a retrospective cohort study. BMC Gastroenterol. 2019; 19(1): 146.

[43] Miyata Y, Mitsunari K, Asai A, Takehara K, Mochizuki Y, Sakai H. Pathological significance and prognostic role of microvessel density, evaluated using CD31, CD34, and CD105 in prostate cancer patients after radical prostatectomy with neoadjuvant therapy. Prostate. 2015; 75(1): 84-91.

[44] Tamaki K, Moriya T, Sato Y, Ishida T, Maruo Y, Yoshinaga K, et al. Vasohibin-1 in human breast carcinoma: A potential negative feedback regulator of angiogenesis. Cancer Sci. 2009; 100: 88-94.

[45] Saito M, Suzuki Y, Yano S, Miyazaki T, Sato Y. Proteolytic inactivation of anti-angiogenic vasohibin-1 by cancer cells. J Biochem. 2016 ; $160: 227-232$. 
[46] Kimura H, Miyashita H, Suzuki Y, Kobayashi M, Watanabe K, Sonoda H, et al. Distinctive localization and opposed roles of vasohibin-1 and vasohibin-2 in the regulation of angiogenesis. Blood. 2009; 113(19): 4810-4818.

[47] Sato Y. Novel link between inhibition of angiogenesis and tolerance to vascular stress. Journal of Atherosclerosis and Thrombosis. 2015; 22 : 327-334.

[48] Hantelys F, Godet AC, David F, Tatin F1, Renaud-Gabardos E1, Pujol F, et al. Vasohibin1, a new mouse cardiomyocyte IRES trans-acting factor that regulates translation in early hypoxia. Elife. 2019; 8. pii: e50094.

\section{Tables}

\begin{tabular}{|c|c|c|c|c|c|c|c|c|c|}
\hline Reference & $\begin{array}{l}\text { Is the } \\
\text { case } \\
\text { definition } \\
\text { adequate? }\end{array}$ & $\begin{array}{l}\text { Representativeness } \\
\text { of the cases }\end{array}$ & $\begin{array}{l}\text { Selection } \\
\text { of } \\
\text { Controls }\end{array}$ & $\begin{array}{l}\text { Definition } \\
\text { of } \\
\text { Controls }\end{array}$ & $\begin{array}{l}\text { Comparability } \\
\text { of cases and } \\
\text { controls on } \\
\text { the basis of } \\
\text { the design or } \\
\text { analysis }\end{array}$ & $\begin{array}{l}\text { Ascertainment } \\
\text { of exposure }\end{array}$ & $\begin{array}{l}\text { Same method } \\
\text { of } \\
\text { ascertainment } \\
\text { for cases and } \\
\text { controls }\end{array}$ & $\begin{array}{l}\text { Non-Response } \\
\text { rate }\end{array}$ & $\begin{array}{l}\text { Total } \\
\text { Scores }\end{array}$ \\
\hline $\begin{array}{l}\text { Yu et al. } \\
\text { [17] }\end{array}$ & ૫ & प & प & ( & प्र & प & प & प & 7 \\
\hline $\begin{array}{l}\text { Yu et al. } \\
\text { [18] }\end{array}$ & प & प & प & प & 吅 & प & प & प & 8 \\
\hline $\begin{array}{l}\text { Ninomiya } \\
\text { et al. [19] }\end{array}$ & ૫ & प & प & ( & 吅 & प & प & प & 8 \\
\hline $\begin{array}{l}\text { Wu et al. } \\
\text { [20] }\end{array}$ & 口 & प & प & ૫ & 吅 & प & प & 口 & 7 \\
\hline $\begin{array}{l}\text { Ma et al. } \\
{[21]}\end{array}$ & प & प & प & प & 吅 & प & प & प & 7 \\
\hline $\begin{array}{l}\text { Sano et } \\
\text { al. [22] }\end{array}$ & प & प & प & ૫ & प्र & प & प & प & 6 \\
\hline $\begin{array}{l}\text { Torii et al. } \\
\text { [23] }\end{array}$ & प & [ & [ & Q & 吅 & 口 & 口 & [ & 6 \\
\hline $\begin{array}{l}\text { Mikami et } \\
\text { al. [24] }\end{array}$ & प & प & प & Q & प्र & प & प & $\square$ & 7 \\
\hline $\begin{array}{l}\text { Shen et al. } \\
\text { [25] }\end{array}$ & प & प & प & Q & 吅 & 口 & प & प & 7 \\
\hline $\begin{array}{l}\text { Liu et al. } \\
{[26]}\end{array}$ & प & प & प & प & 吅 & प & प & 口 & 7 \\
\hline $\begin{array}{l}\text { Murakami } \\
\text { et al. [27] }\end{array}$ & प & प & प & ૫ & प्र & प & प & प & 7 \\
\hline $\begin{array}{l}\text { Yan et al. } \\
\text { [28] }\end{array}$ & प & प & प & ૫ & 吅 & प & प & प & 8 \\
\hline $\begin{array}{l}\text { Zhang et } \\
\text { al. [29] }\end{array}$ & — & प & प & Q & 吅 & प & प & $\square$ & 6 \\
\hline $\begin{array}{l}\text { Kitajima } \\
\text { et al. [30] }\end{array}$ & प & प & प & ૫ & प्र & प & प & प & 7 \\
\hline $\begin{array}{l}\text { Kosaka et } \\
\text { al. [31] }\end{array}$ & प & प & प & Q & 吅 & प & प & प & 7 \\
\hline $\begin{array}{l}\text { Kanomata } \\
\text { et al. [32] }\end{array}$ & Q & प & प & Q & प्र & 口 & प & $\square$ & 6 \\
\hline $\begin{array}{l}\text { Miyazaki } \\
\text { et al. [33] }\end{array}$ & प & प & प & ૫ & 吅 & प & प & प & 7 \\
\hline $\begin{array}{l}\text { Wang et } \\
\text { al. [34] }\end{array}$ & प & Q & Q & Q & 吅 & प & प & प & 6 \\
\hline
\end{tabular}

Notes: $₫$,score; $₫$, not score 


\begin{tabular}{|c|c|c|c|c|c|c|c|c|}
\hline Reference & year & $\begin{array}{l}\text { Tumor } \\
\text { Histology }\end{array}$ & $\begin{array}{l}\text { Case } \\
\text { nationality }\end{array}$ & $\begin{array}{l}\text { Detected } \\
\text { sample }\end{array}$ & Technique & Cut-off value & $\begin{array}{l}\text { Follow-up } \\
\text { time }\end{array}$ & $\begin{array}{l}\text { Quality } \\
\text { score }\end{array}$ \\
\hline Yu et al. [17] & $2019 a$ & Ovary serous carcinoma & China & Tissue & $\mathrm{IHC}$ & Final scores $\geq 3$ & $\begin{array}{l}\text { 6-105 } \\
\text { months }\end{array}$ & 7 \\
\hline Yu et al. [18] & $2019 b$ & Epithelial ovarian cancer & China & Tissue & $\mathrm{IHC}$ & Final scores $\geq 3$ & $\begin{array}{l}\text { 6-105 } \\
\text { months }\end{array}$ & 8 \\
\hline $\begin{array}{l}\text { Ninomiya et } \\
\text { al. [19] }\end{array}$ & 2018 & $\begin{array}{l}\text { Squamous cell carcinoma of } \\
\text { the esophagus }\end{array}$ & Japan & Tissue & $\mathrm{IHC}$ & > Average MVD/VASH1 & 5 years & 8 \\
\hline Wu et al. [20] & 2017 & $\begin{array}{l}\text { Lung squamous cell } \\
\text { carcinoma }\end{array}$ & China & Tissue & $\mathrm{IHC}$ & Final scores $\geq 3$ & $\begin{array}{l}8-71 \\
\text { months }\end{array}$ & 7 \\
\hline Ma et al. [21] & 2017 & Esophageal carcinoma & China & Tissue & $\mathrm{IHC}$ & Mean value $>4$ & N.R & 7 \\
\hline $\begin{array}{l}\text { Sano et al. } \\
\text { [22] }\end{array}$ & 2017 & Ovarian carcinoma & Japan & Tissue & $\mathrm{IHC}$ & $\begin{array}{l}\text { > Median immunostained } \\
\text { vessels }\end{array}$ & $\begin{array}{l}0-143 \\
\text { months }\end{array}$ & 6 \\
\hline $\begin{array}{l}\text { Torii et al. } \\
\text { [23] }\end{array}$ & 2017 & $\begin{array}{l}\text { Head and neck squamous } \\
\text { cell carcinoma }\end{array}$ & Japan & Tissue & $\mathrm{IHC}$ & VASH1 expression $\geq 1.11 \%$ & $\begin{array}{l}\text { 14-194 } \\
\text { months }\end{array}$ & 6 \\
\hline $\begin{array}{l}\text { Mikami et al. } \\
\text { [24] }\end{array}$ & 2017 & Renal cell carcinoma & Japan & Tissue & $\mathrm{IHC}$ & VASH1 density $\geq 268.8$ & N.R & 7 \\
\hline $\begin{array}{l}\text { Shen et al. } \\
\text { [25] }\end{array}$ & 2015 & Gastric carcinoma & China & Tissue & $\mathrm{IHC}$ & $\begin{array}{l}\text { Combined staining score } \geq \\
5\end{array}$ & N.R & 7 \\
\hline Liu et al. [26] & 2015 & Colorectal carcinoma & China & Tissue & $\mathrm{IHC}$ & N.R & N.R & 7 \\
\hline $\begin{array}{l}\text { Murakami et } \\
\text { al. [27] }\end{array}$ & 2014 & Hepatocellular carcinoma & Japan & Tissue & $\mathrm{IHC}$ & VASH1/CD34 > 0.459 & $\begin{array}{l}\text { median } 36 \\
\text { months }\end{array}$ & 7 \\
\hline $\begin{array}{l}\text { Yan et al. } \\
\text { [28] }\end{array}$ & 2014 & Colorectal carcinoma & China & Tissue & $\mathrm{IHC}$ & $\begin{array}{l}\text { Combined staining score } \geq \\
\text { 5s }\end{array}$ & $\begin{array}{l}4-83 \\
\text { months }\end{array}$ & 8 \\
\hline $\begin{array}{l}\text { Zhang et al. } \\
\text { [29] }\end{array}$ & 2014 & $\begin{array}{l}\text { Non-small cell lung } \\
\text { carcinoma }\end{array}$ & China & Tissue & $\mathrm{IHC}$ & $\begin{array}{l}\text { Immunohistochemical } \\
\text { expression level } \geq 150 \%\end{array}$ & 52 months & 6 \\
\hline $\begin{array}{l}\text { Kitajima et } \\
\text { al. [30] }\end{array}$ & 2014 & Colorectal carcinoma & Japan & Tissue & $\mathrm{IHC}$ & $\mathrm{IHC}$ score $\geq 6$ & $\begin{array}{l}0.13-118.4 \\
\text { months }\end{array}$ & 7 \\
\hline $\begin{array}{l}\text { Kosaka et al. } \\
\text { [31] }\end{array}$ & 2013 & Prostate carcinoma & Japan & Tissue & $\mathrm{IHC}$ & $\begin{array}{l}\text { VASH1 density } \geq 12 \text { per } \\
\mathrm{mm} 2\end{array}$ & 4.9 years & 7 \\
\hline $\begin{array}{l}\text { Kanomata et } \\
\text { al. [32] }\end{array}$ & 2013 & Renal cell carcinoma & Japan & Tissue & $\mathrm{IHC}$ & N.R & 3026 days & 6 \\
\hline $\begin{array}{l}\text { Miyazaki et } \\
\text { al. [33] }\end{array}$ & 2012 & Urothelial carcinoma & Japan & Tissue & $\mathrm{IHC}$ & $>$ median value & $\begin{array}{l}0.7-20 \\
\text { years }\end{array}$ & 7 \\
\hline $\begin{array}{l}\text { Wang et al. } \\
\text { [34] }\end{array}$ & 2011 & Hepatocellular carcinoma & China & Tissue & $\mathrm{IHC}$ & $\begin{array}{l}\text { Immunohistochemical score } \\
(\mathrm{H} \text {-score }) \geq 6\end{array}$ & $\begin{array}{l}5-62 \\
\text { months }\end{array}$ & 6 \\
\hline
\end{tabular}

Notes: IHC, immunohistochemistry 


\begin{tabular}{|c|c|c|c|c|c|c|c|}
\hline & $\mathrm{N}^{\mathrm{a}}$ & VASH $1+^{\mathrm{b}}$ & VASH1-c & OR $(95 \% \mathrm{Cl})^{*}$ & $P^{d}$ & $\operatorname{HR}(95 \% \mathrm{Cl})^{*}$ & $P^{d}$ \\
\hline \multicolumn{8}{|c|}{ TNM stage (3/4) } \\
\hline Total & 10 & 723 & 854 & $1.96(1.57-2.46)$ & 0.106 & - & - \\
\hline \multicolumn{8}{|c|}{ Tumor stage (T3/T4) } \\
\hline Total & 10 & 723 & 854 & $2.35(1.88-2.93)$ & 0.157 & - & - \\
\hline \multicolumn{8}{|c|}{ Lymph node metastasis (N1-N3) } \\
\hline Total & 9 & 668 & 703 & $2.02(1.37-2.98)$ & 0.030 & - & - \\
\hline \multicolumn{8}{|c|}{ Distant metastasis (M1) } \\
\hline Total & 5 & 385 & 474 & $1.81(0.74-4.41)$ & 0.019 & - & - \\
\hline \multicolumn{8}{|c|}{ Venous invasion } \\
\hline Total & 5 & 430 & 522 & $1.63(1.00-2.65)$ & 0.036 & - & - \\
\hline \multicolumn{8}{|c|}{ Tumor grade } \\
\hline Total & 11 & 900 & 979 & $1.74(1.13-2.67)$ & $<0.001$ & - & - \\
\hline \multicolumn{8}{|c|}{ Microvessel density (MVD) } \\
\hline Total & 4 & 416 & 468 & $4.30(2.31-8.03)$ & 0.006 & - & - \\
\hline \multicolumn{8}{|c|}{ Disease-free survival (DFS) } \\
\hline Total & 6 & 321 & 441 & - & - & $1.80(1.41-2.29)$ & 0.302 \\
\hline \multicolumn{8}{|c|}{ Overall survival (OS) } \\
\hline Total & 13 & 761 & 922 & - & - & $1.85(1.27-2.69)$ & $<0.001$ \\
\hline \multicolumn{8}{|c|}{ a Number of studies } \\
\hline \multicolumn{8}{|c|}{ b Number of VASH1 positive (or high) patients } \\
\hline \multicolumn{8}{|c|}{ c Number of VASH1 negative (or high) patients } \\
\hline d Ran & eff & model wa & d when $p$ & e for heterogen & $<0.1 ; 0$ & ise, fixed-effects & was use \\
\hline
\end{tabular}

\section{Figures}




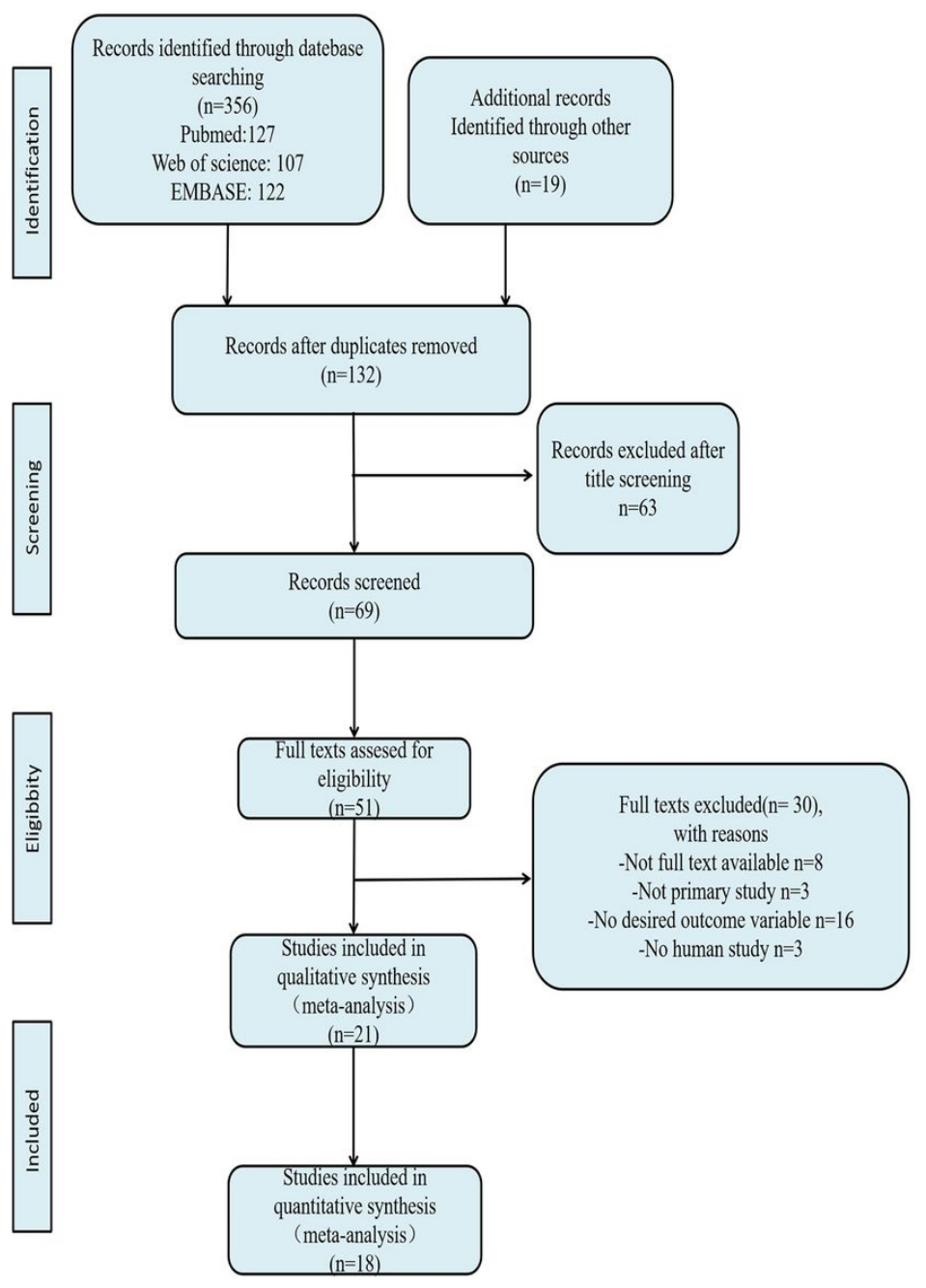

Figure 1

Flow diagram of literature search and selection process. 
A

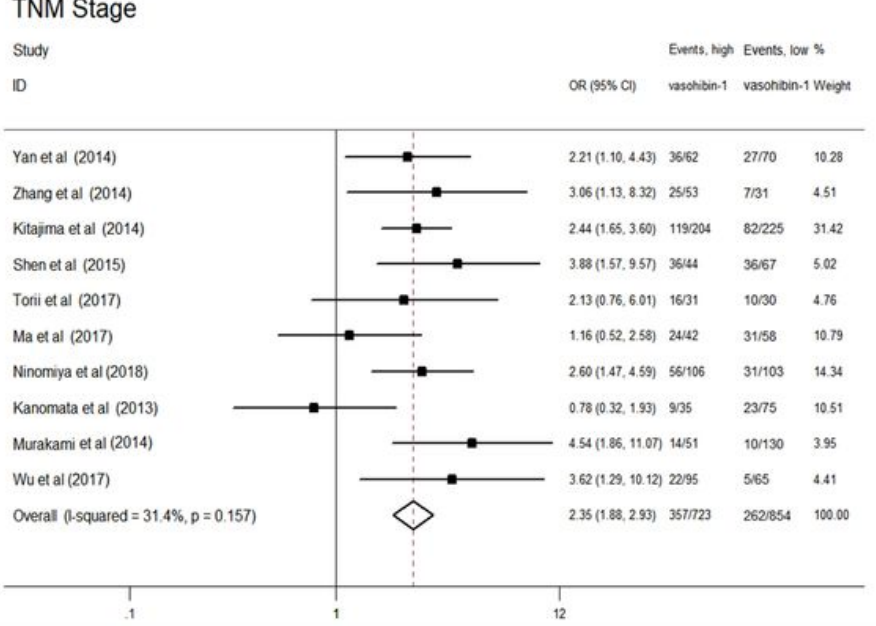

C

$\mathrm{N}$ Lymph node metastasis

Study

10

Yanet al (2014)

Zhang et al (2014)

Ktajima et al (2014)

Shen et al (2015)

Tori et al (2017)

Ninomiya et al (2018)

Kanomata et al (2013)

Livet al (2015)

Wuet al (2017)

Overal (1.squared $=52.9 \%, p=0.030$ )

NOTE. Weights are trom random effects analysis

.0001
B

Tumor Stage

Study

Events. nign Events, low \%

OR (95\% Cl) vasohioin-1 vasohibin-1 Weight

\begin{tabular}{|c|c|c|c|c|c|}
\hline Wang et al (2011) & $\rightarrow$ & $1.47(0.50 .4 .39)$ & $7 / 45$ & $8 / 2$ & 4.82 \\
\hline Miyazaki et al (2012) & 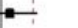 & $1.22(0.70,2.13)$ & $62 / 113$ & $44 / 88$ & 20.73 \\
\hline Kosaka et al (2013) & & $271(1.38,5.33)$ & $36 / 84$ & $12 / 23$ & 9.61 \\
\hline Yanet al (2014) & & $5.00(1.05,23.79)$ & 60162 & $60 / 70$ & 1.69 \\
\hline Zhang et al (2014) & & $2.17(0.55,8.59)$ & 10/53 & 3/31 & 2.85 \\
\hline Kitäma et al (2014) & & $2.25(1.46,3.48)$ & $162 / 204$ & $142 / 225$ & 25.81 \\
\hline Shen et al (2015) & & $4.55(1.69,12.22)$ & $38 / 44$ & $39 / 67$ & 3.91 \\
\hline Torii et al (2017) & & $2.89(0.92,9.07)$ & 13/31 & $6 / 30$ & 320 \\
\hline Ninomiya et al (2018) & & $1.87(1.07 .327)$ & $52 / 106$ & $35 / 103$ & 16.79 \\
\hline Kanomata et al (2013) & - & $0.63(0.24,1.63)$ & $7 / 37$ & 23,85 & 10.50 \\
\hline Overall (1-squared $=37.9 \%, p=0.106)$ & $\diamond$ & $1.96(1.57,2.46)$ & $447 \pi 79$ & $378 / 854$ & 100.00 \\
\hline
\end{tabular}

D

M Distant metastasis

Study $\quad$ Everts, high Events, low :

ID

OR (955 C) vasohibin-1 vasohibin.1 Weight

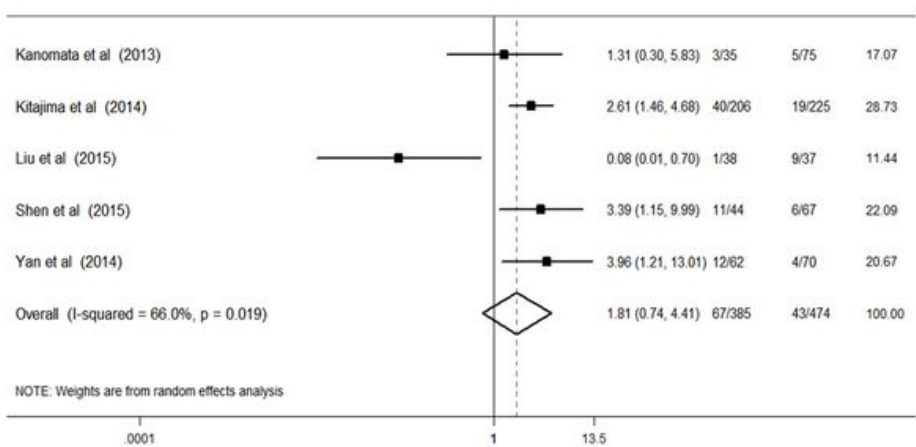

Figure 2

Forest plots of TNM stage, tumor stage (T stage), lymph node metastasis ( $\mathrm{N}$ stage), distant metastasis (M stage). Notes: A : The forest plot of TNM stage; B : The forest plot of tumor stage; $\mathrm{C}$ : The forest plot of lymph node metastasis; D : The forest plot of distant metastasis. 
A

Venous invasion

Study

ID

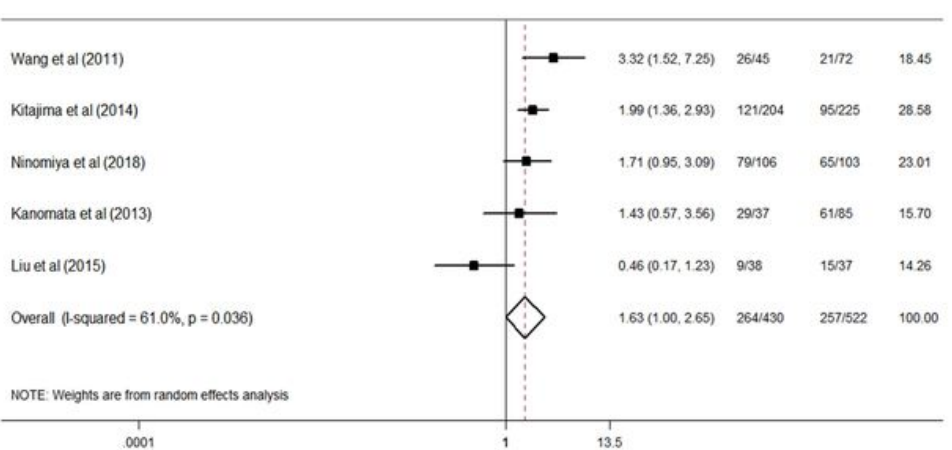

C

MVD Microvessel density

Study

ID

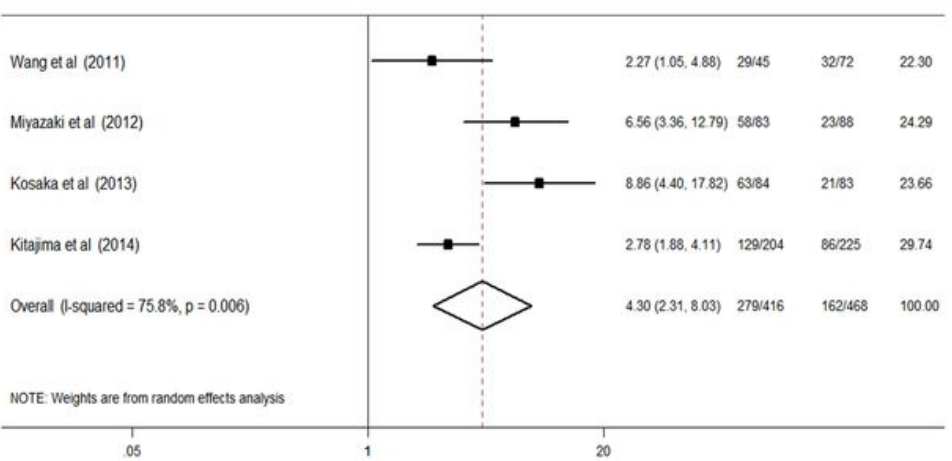

udy

OR $(95 \%$ C) vasonion-1 vasohbin-1 weight
B

Grade

Study $\quad$ Events, high Events, low s

ID

OR $(95 \% \mathrm{Cl})$ vasonioin-1 vasohion-1 Weight

$\begin{array}{llll}1.47(0.50 .439) & 7 / 45 & 8 / 2 & 7.27\end{array}$ $1.95(1.01,3.75) \quad 6283 \quad 53886 \quad 10.43$ $\begin{array}{llll}0.97(0.42 .225) & 13.62 & 1570 & 9.03\end{array}$ $\begin{array}{llll}1.61(0.64 .4 .07) & 23 / 53 & 10 / 31 & 8.35\end{array}$ $0.90(0.47 .1 .70) \quad 183204 \quad 204 / 225 \quad 10.56$ $\begin{array}{llll}1.85(0.46 .7 .41) & 41 / 44 & 5967 & 5.64\end{array}$ $\begin{array}{llll}1.00(0.55,1.79) & 73 / 106 & 71 / 103 & 10.95\end{array}$ $\begin{array}{llll}1.27(0.45 .3 .54) & 11 / 38 & 9 / 37 & 7.68\end{array}$ $6.29(2.87 .13 .77) \quad 2251 \quad 14 / 130 \quad 9.42$ $1.37(0.65 .289) \quad 26.95 \quad 14655 \quad 9.73$ $\begin{array}{llll}4.84(2.69 .871) & 85 / 119 & 31 / 91 & 10.93\end{array}$ $1.74(1.13 .267) \quad 54619000 \quad 4889979 \quad 100.00$
Overall (.-squared $=69.1 \%, p=0.000$ )

NOTE: Weights are from random eflects analysis

$\frac{\text { NOTE: Weights are from rancom effects analysis }}{10}$

Miyazaki et al (2012)

Zhang et al (2014)

Shen et al (2015)

ive et al (2015)

Murakami et al (2014)

Wuet al (2017) 
A

DFS Disease free survival

Study

ID

HR $(95 \% \mathrm{Cl}) \quad$ Weight

-

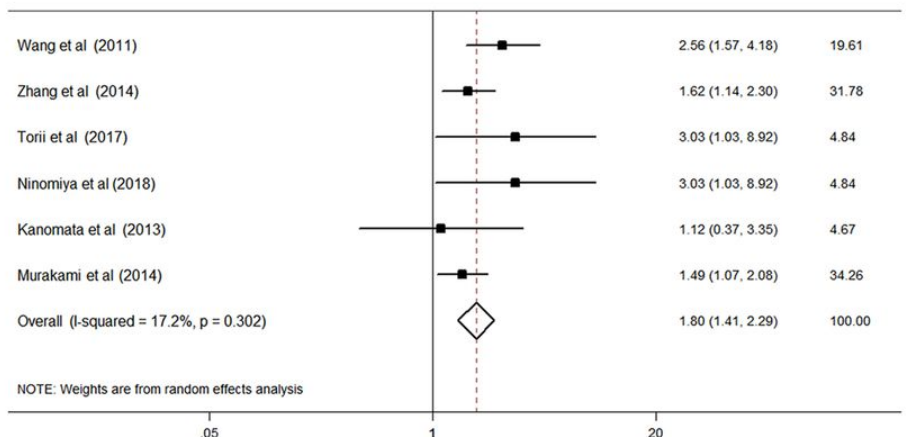

B

OS Overall survival

Study

ID

$\mathrm{HR}(95 \% \mathrm{Cl}) \quad$ Weight

Wang et al (2011)

Yan et al (2014)

Zhang et al (2014)

Kitajima et al (2014)

Shen et al (2015)

Mikami et al (2017)

Sano et al (2017)

Ma et al (2017)

Ninomiya et al (2018)

Kanomata et al (2013)

Murakami et al (2014)

Yu 2019a et al (2019)

Yu 2019b et al (2019)

Overall (l-squared $=80.0 \%, p=0.000$ )

NOTE: Weights are from random effects analysis

.05

$2.23(1.34,3.70) \quad 8.55$

$2.53(1.35,4.75) \quad 7.90$

$1.52(0.80,2.91) \quad 7.79$

$1.05(0.63,1.75) \quad 8.55$

$2.80(1.56,5.04) \quad 8.12$

$3.42(1.08,10.87) \quad 5.15$

$1.80(0.39,8.32) \quad 3.76$

$0.67(0.33,1.36) \quad 7.46$

$1.60(1.02,2.51) \quad 8.85$

$0.49(0.27,0.88) \quad 8.12$

$2.16(1.27,3.67) \quad 8.44$

$4.35(2.66,7.10) \quad 8.65$

$4.14(2.53,6.75) \quad 8.65$

$1.85(1.27,2.69) \quad 100.00$

\section{Figure 4}

Forest plots of DFS and OS time. Abbreviations: OS, overall survival; PFS, progression-free survival Notes: A: Forest plots of DFS; B: Forest plots of OS. 

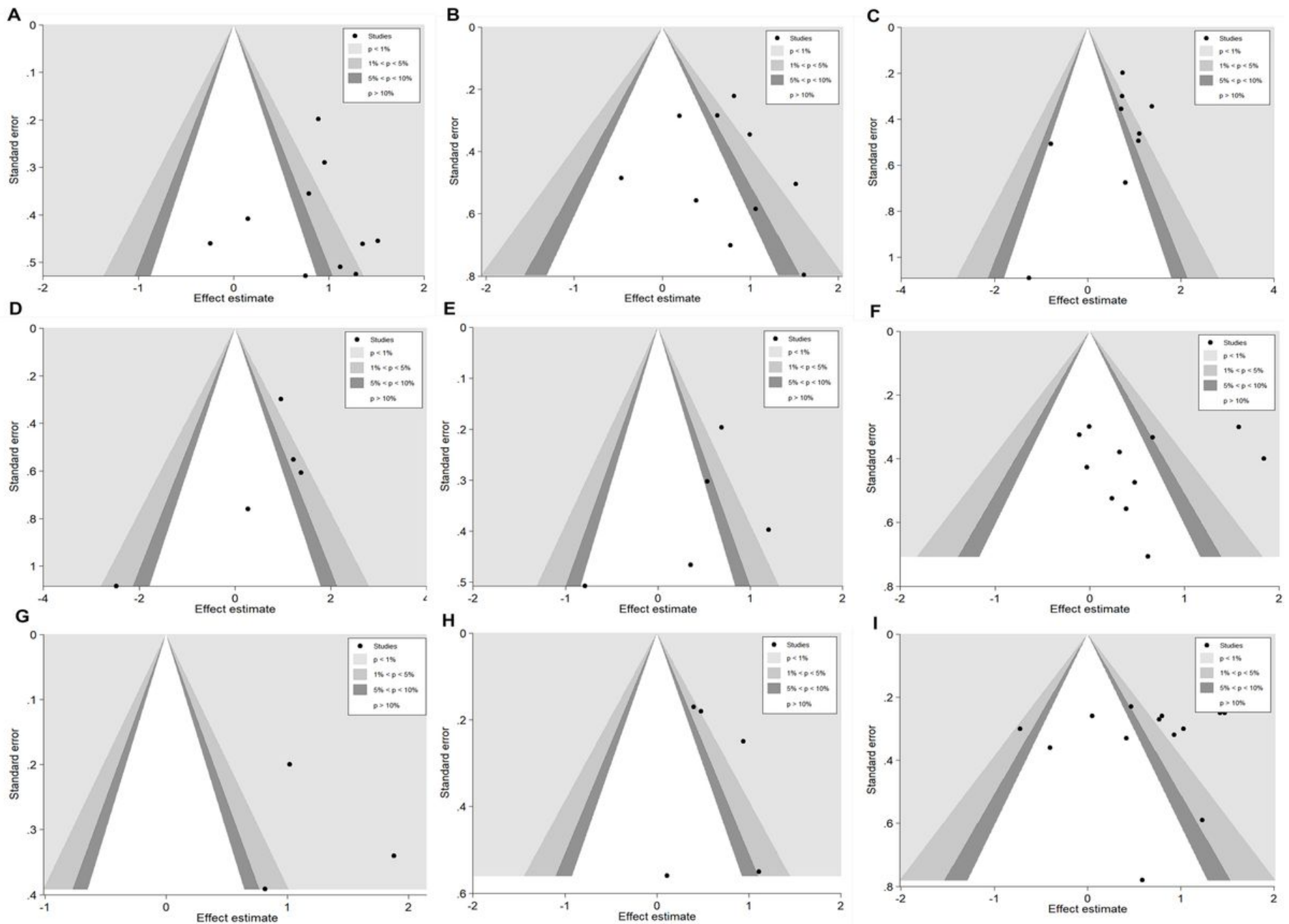

Figure 5

Funnel plots of TNM stage, tumor stage, lymph node metastasis, distant metastasis, venous invasion, tumor grade, MVD, DFS and OS time. Notes: A : The funnel plots of TNM stage; $B$ : The funnel plot of tumor stage; $C$ : The funnel plot of lymph node metastasis; $D$ : The funnel plot of distant metastasis; $E$ : The funnel plot of venous invasion; $F$ : The funnel plot of tumor grade; $G$ : The funnel plot of MVD; $H$ : The funnel plot of DFS time; I : The funnel plot of OS time.

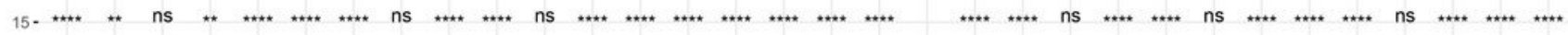

10.

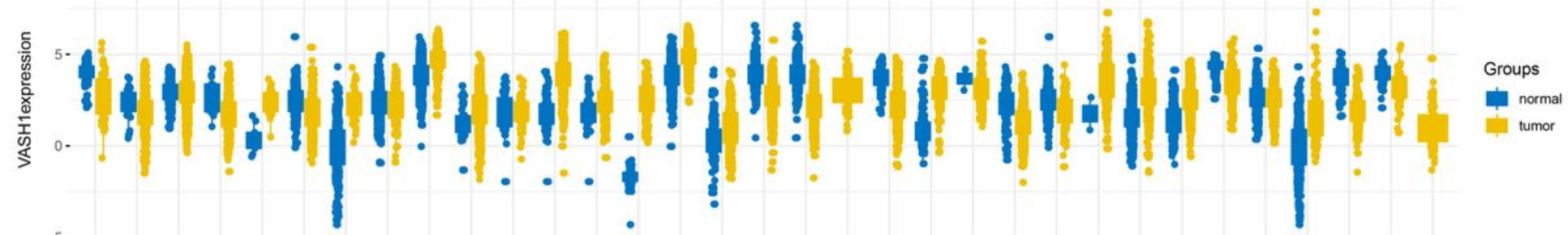

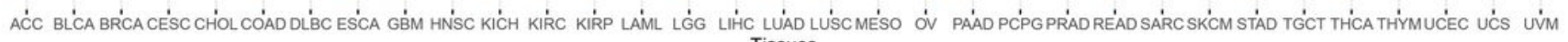
Tissues

Figure 6

\section{Supplementary Files}

This is a list of supplementary files associated with this preprint. Click to download. 
- PRISMA2009checklist.doc

- Figurecaptionsandlegends.docx

- SupplementaryFigure1.tif

Page 16/16 